Ключевые слова: незаконное лишение свободы, похищение человека, длительное время оценочное понятие, квалифицирующий признак.

Sasko O. The Length of Time: an Evaluative Concept in Article 146 of the Criminal Code of Ukraine. The article considers issues related to the qualifying feature of the crime under Art. 146 of the Criminal Code (CC) of Ukraine, acts carried out for a long time. In this norm, the legislator defined the concept of «long/lasting time» as a certain astronomical period during which the detention of the victim in captivity may increase the social danger. However, this rule does not define the time required to disclose the content of this valuation concept. Therefore, the definition of a qualifying feature automatically became the competence of law enforcement agencies and criminal law doctrine. The author argues that some formalization of the concept is necessary to give this feature a general specificity, direction, and clarity of its implication boundaries. The analysis of investigative and judicial practice shows that the lack of a single legal position of law enforcement agencies on the qualification of acts on the grounds of a crime under Part 2 of Art. 146 of the Criminal Code of Ukraine, complicates the activities of the court to make lawful and reasonable decisions. A more precise theoretical definition of such a qualifier as unlawful deprivation of liberty or kidnapping for a long time is needed. The moment of the end of a person's abduction in the legal literature and law enforcement practice is generally considered to be the moment of committing actions aimed at taking possession of the victim in any way and then moving him from one place to another. The author suggests amending Article 146 of the Criminal Code of Ukraine with a note in which to determine that long time should be understood as the unlawful deprivation of liberty, lasting for more than three days.

Key words: illegal/unlawful deprivation of liberty, kidnapping, long time, evaluation concept, qualifying feature.

УДК 343.622(477)

DOI https://doi.org/10.32782/2409-4544/2020-1/21

О. Старко

\title{
Злочини проти життя та здоров'я особи: кількісно-якісні показники за 2013-2019 рр.
}

Статтю присвячено проблемі кримінологічної характеристики злочинів проти життя і здоров'я людини на сучасному етапі. Зокрема, досліджено питання про кількісно-якісні показники даного виду злочинності за період 2013-2019 pр. Кількісно-якісні виміри злочинності слугують одним із основних орієнтирів як для корекції запроваджених заходів запобігання, так і пошуку нових та ефективніших способів протидії, а отже повинні бути постійним об'єктом системного кримінологічного спостереження. 2013-2014 рр. відзначились ескалацією кількісно-якісних вимірів злочинів проти життя та здоров'я особи, а 2015-2019 рр. подальшою стабілізацією дещо знижених показників. Злочини проти життя та здоров'я особи, та особливо їх насильницький сегмент, який за останні сім років сягнув 96\%, характеризуються високим ступенем суспільної небезпечності. Наводено i проаналізовано дані про рівень злочинів і осіб, які їх вчинили, коефіцієнти, що характеризують кримінальну активність населення і інтенсивність злочинів цього виду на території України. Здійснено аналіз структури злочинів, а також структури відповідних груп злочинів. Автором констатовано стабільність основних структурних показників злочинів проти життя і здоров'я людини (84\% складають злочини проти здоров'я, 14,3\% - злочини проти життя, 1,96\% - злочини, що ставлять в небезпеку життя і здоров'я людини). Найбільш поширеними є: умисні легкі тілесні ушкодження $(63,7 \%)$, умисні вбивства без обтяжуючих і пом'якшуючих обставин (12\%), умисні середньої тяжкості тілесні ушкодження (7,2\%), умисні тяжкі тілесні ушкодження (4,9\%), побої і мордування $(3,2 \%)$. Констатовано стрімке зростання рівня злочинів проти життя і здоров'я людини у 2013-2014 рр., а також збільшення питомої ваги їх насильницького сегменту майже до $100 \%$, що свідчить не тільки про їх сімейно-побутовий і ситуаційний характер, але і про вагому роль суспільно політичної складової їх обумовленості.

(C) Старко O., 2020 
Ключові слова: злочини проти життя та здоров'я особи, вбивства, тілесні ушкодження, рівень, структура, коефіціенти злочинності, статистичні дані.

Постановка наукової проблеми та іїі значення. 2013-2014 рр. відзначились ескалацією кількісно-якісних вимірів злочинів проти життя та здоров'я особи, а 2015-2019 рр. подальшою стабілізацією дещо знижених показників. Злочини проти життя та здоров'я особи, та особливо їх насильницький сегмент, який за останні сім років сягнув $96 \%$, характеризуються високим ступенем суспільної небезпечності.

Кількісно-якісні виміри злочинності слугують одним із основних орієнтирів як для корекції запроваджених заходів запобігання, так і пошуку нових та ефективніших способів протидії, а отже повинні бути постійним об' єктом системного кримінологічного спостереження.

Аналіз досліджень цієї проблеми. Проблеми кримінологічної характеристики злочинів проти життя та здоров'я особи вивчались багатьма вченими-кримінологами. Це, зокрема, роботи Г. А. Аванесова, В. В. Голіни, А. І. Долгової, І. М. Даньшина, О. М. Джужи, А. П. Закалюка, А. Ф. Зелінського, В. М. Кудрявцева, І. П. Лановенка, О. М. Литвака, І. К. Туркевич, В. І. Шакуна та ін.

Формулювання мети та завдань статті. Метою статті є аналіз кількісно-якісних показників (рівня, коефіцієнтів, структури) злочинів проти життя та здоров'я особи за останні сім років (20132019 рр.) на основі даних офіційної статистики.

Виклад основного матеріалу й обгрунтування отриманих результатів дослідження.

У теорії кримінального права злочини проти життя та здоров'я особи класифікують, як правило, за критерієм видового об'єкта на три групи:

1. Злочини проти життя особи: вбивства (ст.ст. 115-119 Кримінального кодексу (далі - КК) України) та доведення до самогубства (ст. 120 КК України);

2. Злочини проти здоров'я особи: тілесні ушкодження (ст.ст. 121-125, ст. 128 КК України), завдання фізичних або моральних страждань (ст.ст. 126-127, ст. 129 КК України), зараження соціальними хворобами (ст. 130, ст. 133 КК України);

3. Злочини, що ставлять у небезпеку життя та здоров'я особи, які поділяють на дві підгрупи: а) злочини, які вчиняються у сфері медичного обслуговування (ст.ст. 131, 132, 138-145 КК України); б) інші злочини, які ставлять у небезпеку життя та здоров'я особи (ст.ст. 134- 137 КК України) [1, c. 37-38].

Характеризуючи абсолютні (рівень, тобто кількість зареєстрованих злочинів та осіб, що їх вчинили за певний період часу на території України) та відносні (коефіцієнти цих видів злочинів) показники злочинів проти життя та здоров'я особи, відзначимо наступне.

За останні сім років (2013-2019 рр.) в Україні було обліковано 351821 злочинів проти життя та здоров'я особи (ст.ст. 115-145 КК України [2]), що становить 9,5 \% у загальній структурі злочинності. 32016 р. по 2019 р. обліковано 444150 виявлених осіб, які їх вчинили [3], що становить 16,3 \% від усіх виявлених осіб, які вчинили злочини.

Найвищий рівень злочинів проти життя та здоров'я особи було зафіксовано у 2013 р. (71749) та у 2014 р. (61760). 32015 р., їх рівень поступово знижувався, а у 2019 р. дещо зріс. Так, у 2015 р. було обліковано 53794 цих злочинів, у 2016 р. - 45979, у 2017 р. - 38274, у 2018 р. - 39164, а у 2019 р. $-41101[2]$.

Зростання рівня цього виду злочинності саме у 2013-2014 р. відбулось за рахунок стрімкого збільшення числа простих умисних вбивств, легких та середньої тяжкості тілесних ушкоджень. Так, у 2013 р. було обліковано 50018 легких тілесних ушкоджень, що у два рази більше, ніж у 2018 р. У 2014 р. було обліковано 9919 простих умисних вбивств, що також у 2 рази більше, ніж у 2019 р., а також й у період з 1999 р. по 2006 р. Зростання рівня саме цих видів злочинів, є наслідком подій, пов'язаних 3 Революцією гідності у кінці 2013 р. - початку 2014 р., а також початком військових дій на Сході України.

У порівнянні з 2000-ми та навіть 3 90-ми роками, рівень умисних вбивств за останні сім років зріс, у середньому, більш ніж у два рази. Так, у 90-ті роки рівень умисних вбивств (лише за ст. 115 КК України) не перевищував 5 тисяч (у 1993 р. - 4008, у 1996 р. - 4896, у 1999 р. - 4624). В 2000-х роках кількість зареєстрованих вбивств знижувалась, не перевищуючи 4 тисяч, а у деякі роки 2,5 тисяч вбивств (у 2003 р. зареєстровано 3875 вбивств, у 2005 р. - 3315, у 2007 р. - 2906, у 2010 р. - 2356, у 2012 р. - 2048 вбивств) [4]. Проте, починаючи з 2013 р., абсолютна кількість облікованих умисних вбивств (ст. 115 КК України) зросла у декілька разів. Так, за 2013 р. було обліковано 5861 умисне вбивство, за 2014 р. - 11466, за 2015 р. - 8224, за 2016 р. - 5992, за 2017 р. - 5145, за 2018 р. - 5557. I 
лише у 2019 р. їх рівень знизився до 5465 злочинів [2].

Що стосується кількісних показників злочинів, які ставлять у небезпеку життя та здоров'я особи, зокрема їх рівня, зазначимо, що ця величина за останні сім років має відносно стабільні показники. Так, у середньому щороку було обліковано близько тисячі злочинів. Найвищий їх рівень було зафіксовано у 2017 р. за ст. 140 КК України (Неналежне виконання професійних обов'язків медичним або фармацевтичеим працівником) та у 2018 р. - за ст. 135 КК України (Залишення у небезпеці).

Проаналізуємо відносні показники, які дають змогу отримати більш повну картину щодо поширення злочинності - коефіціент інтенсивності злочинності та коефіціент злочинної активності. Коефіціент інтенсивності злочинності відображає те, як населення страждає від злочинності, ступінь враженості певним видом злочинності населення України за певний період часу (яка кількість злочинів припадає на, скажімо 100 тис. населення). Коефіціент злочинної активності відображає те, як інтенсивно продукуються злочинні діяння населенням віку кримінальної відповідальності (від 14 років).

Наведемо показники цих коефіціентів за період 2013-2019 р., стосовно: 1) усіх злочинів, які передбачені розділом II “Злочини проти життя та здоров”я особи”; 2) умисних вбивств, передбачених ст.ст. 115-118 КК України; 3) умисних тяжких тілесних ушкоджень (ст. 121 КК України).

Коефіціент інтенсивності злочинів проти життя та здоров'я особи у розрахунку на 100 тисяч населення становив: у 2013 р. - 158 злочинів, у 2014 р. - 136, у 2015 р. - 126, у 2016 р. - 108, у 2017 р. - 90, у 2019 р. - 98. Таким чином, індекс інтенсивності злочинності був найвищим у 2013 p. (припадало 158 злочинів на 100 тисяч населення), а найнижчий у 2017 р. (припадало 90 злочинів - на 100 тисяч населення).

Інтенсивність умисних вбивств, передбачених ст.ст. 115 -118 КК України (умисного вбивства, вчиненного у стані сильного душевного хвилювання, умисного вбивства матір'ю своєї новонародженої дитини, умисного вбивства при перевищенні меж необхідної оборони або у разі перевищення заходів, необхідних для затримання злочинця) відображена сукупно у наступних індексах: у 2013 p. - 13, у 2014 p. - 25,4, у 2015 p. - 19,4, у 2016 p. - 14,2, у 2017 p. - 12,2, у 2018 p. 13,3, у 2019 р. - 13,1. Отже, найвищий індекс інтенсивності був у 2014 р. - 25 злочинів на 100 тисяч населення, а найнижчий у 2017 р. - 12 злочинів на 100 тисяч населення.

Інтенсивність умисних тяжких тілесних ушкоджень була такою: у 2013 p. - 6,6, у 2014 р. - 6,9, у 2015 p. - 5,9, у 2016 p. - 5,3, у 2017 p. - 4,9, у 2018 p. - 5, у 2019 p. - 4,6. Отже, найвищий індекс інтенсивності був у 2014 р. - майже 7 злочинів на 100 тисяч населення, а найнижчий у 2019 р. - 4,6 злочинів.

Показники коефіціента злочинної активності наведемо згідно даних Єдиного звіту про осіб, які вчинили кримінальні правопорушення, який подається Офісом Генерального прокурора лише 3 2016 р. Стосовно всіх злочинів проти життя та здоров'я: у 2016 р. - 47,3, у 2017 р. - 51, у 2018 р. 51,6, у 2019 р. - 52,9. Таким чином, найвищий індекс злочинної активності був у 2019 р. - 53, а найнижчий у 2016 р. - 47,3.

Щодо показників злочинної активності щодо умисних вбивств та тяжких тілесних ушкоджень, суттєвих коливань не відмічено. Індекси злочинної активності умисних вбивств (ст. 115 та ст. 118 КК України) були такі: у 2016 р. - 3, у 2017 p. - 2,9, у 2018 р. - 2,9, у 2019 р. - 2,7. Отже, найвищий показник був у 2016 р. - 3, а найнижчий у 2019 р. - 2,7.

Індекси злочинної активності умисних тяжких тілесних ушкоджень $є$ наступні: у 2016 р. - 4,1, у 2017 p. - 4,3, у 2018 p. - 4,7, у 2019 p. - 4,3. Тобто, найвищий у 2018 p. - 4,7, а найнижчий у 2016 р. $-4,1$.

Якісним показником злочинності є іiї структура - внутрішня будова злочинності, яка означає відношення окремого виду або групи злочинів до всієї маси злочинності на певній території за конкретний період. Аналіз офіційних статистичних даних (облікованих кримінальних правопорушень) показує, що найпоширенішими у структурі злочинів проти життя та здоров'я особи $\epsilon$ злочини проти здоров'я, їх питома вага складає $84 \%$. Дана група злочинів, як зазначалось вище, включає в себе тілесні ушкодження (ст.ст. 121-125, ст. 128 КК України), завдання фізичних або моральних страждань (ст.ст. 126-127, ст. 129 КК України), зараження соціальними хворобами (ст. 130, ст. 133 КК України).

У структурі злочинів проти здоров’я 92,7 \% складають тілесні ушкодження, з яких 76, \% це легкі тілесні ушкодження (ст. 125 КК України), 8,6 \% - умисні середньої тяжкості тілесні ушкодження та 5,8 \% умисні тяжкі тілесні ушкодження.

Питома вага «завдання фізичних або моральних страждань» у структурі злочинів проти 
здоров'я становить - 7,2\%. Серед цієї групи злочинів $52 \%$ становлять побої та мордування (ст. 126 КК України) та $41 \%$ - погроза вбивством ( ст. 129 КК України). Нещодавно криміналізоване домашнє насильство (ст. 126-1 КК України) становить 5 \% (згідно даних за 2019 р. було обліковано 1068 кримінальних правопорушень).

Зараження соціальними хворобами має мізерну питому вагу - 0,02 \%, в основному за рахунок злочинів, що передбачені ст. 130 КК України (зараження вірусом імунодефіциту людини та іншої невиліковної інфекційної хвороби). Проте, слід зазначити, що ця група злочинів має високий ступінь латентності.

На другому місці у структурі злочинів проти життя та здоров'я особи - злочини проти життя, ïx частка складає 14,3 \%. Структура злочинів проти життя виглядає наступним чином: 84,1 \% становлять прості умисні вбивства (ч. 1 ст. 115 України), $11 \%$ становлять кваліфіковані умисні вбивства (ч. 2 ст. 115 КК України), 2,3 \% - необережне вбивство (ст. 119 КК України), 1,9 \% доведення до самогубства (ст. 120 КК України) та 0,7 \% становлять привілейовані умисні вбивства (ст.ст. 116-118 КК України).

Умисні вбивства (ст.ст. 115-118 КК України) у структурі злочинів проти життя і здоров'я становлять $13,7 \%$. Серед них, частка простих умисних вбивств складає 87,8 \%, кваліфікованих умисних вбивств (ч. 2 ст. 115 КК України) - 11,5 \%, привілейованих умисних вбивств - 0,8 \%.

У структурі кваліфікованих умисних вбивств найбільшу питому вагу мають умисні вбивства двох і більше осіб (п. 1 ч. 2 ст. 115 КК України) - $25 \%$, умисні вбивства, вчинені за попередньою змовою групою осіб (п. 12 ч. 2 ст. 115 КК України) - 16,4 \%, умисні вбивства 3 корисливих мотивів (п. 6 ч. 2 ст. 115 КК України) - 14,6\%, умисні вбивства, вчинені особою, яка раніше вчинила умисне вбивство, за винятком вбивства, передбаченого статтями 116-118 КК України (п. 13 ч. 2 ст. 115 КК України) - 10,2 \% та умисні вбивства, малолітньої дитини або жінки, яка завідомо для винного перебувала у стані вагітності (п. 2 ч. 2 ст. 115 КК України) - 8,7\%. Частка вбивств, вчинених 3 особливою жорстокістю - 3,1\%. Практично відсутні у структурі кваліфікованих умисних вбивств, вбивства заручника або викраденої людини $(0,3 \%)$, та умисні вбивства 3 мотивів расової, національної чи релігійної нетерпимості (лише 2 обліковані злочини за останні сім років).

У структурі привілейованих умисних вбивств, 62 \% складають умисні вбивства, вчинені при перевищенні необхідної оборони або у разі перевищення заходів, необхідних для затримання злочинця, 25,5 \% - умисні вбивства матір'ю своєї новонародженої дитини та 12,6 \% - умисні вбивства, вчинені у стані сильного душевного хвилювання. Третє місце у структурі злочинів проти життя та здоров'я особи посідають злочини, що ставлять у небезпеку життя та здоров'я особи, їх питома вага становить $1,96 \%$. Ці злочини поділяють на дві підгрупи: злочини, що вчиняються у сфері медичного обслуговування населення (ст. ст. 131, 132, 138- 145 КК України) та інші злочини, що ставлять у небезпеку життя та здоров'я особи (ст.ст. 134-137 КК України).

Зазначимо, що у структурі злочинів, що ставлять у небезпеку життя та здоров'я особи, 68,5 \% це злочини, що вчиняються у сфері медичного обслуговування населення. У структурі цих злочинів, 91,5 \% займають неналежне виконання професійних обов'язків медичним або фармацевтичним працівником (ст. 140 КК України).

Щодо інших злочинів, що ставлять у небезпеку життя та здоров'я особи, 68 \% становить залишення в небезпеці (ст. 135 КК України). Таким чином, найбільшу питому вагу у структурі злочинів III групи становлять неналежне виконання професійних обов'язків медичним або фармацевтичним працівником (ст. 140 КК України) - 62,7 \% та залишення в небезпеці (ст. 135 КК України) $-21 \%$.

Висновки. Результати дослідження кількісно-якісних показників злочинів проти життя та здоров'я особи за 2013 - 2019 рр., свідчать про наступне:

1) рівень тілесних ушкоджень (легких та середньої тяжкості) та умисних вбивств (ч. 1 ст. 115 КК України) зріс у 2-2,5 рази у порівнянні з 2000-ми та навіть 90-ми роками. Враховуючи відсутність офіційних статистичних даних з окупованих частин Донецької та Луганської областей та Автономної республіки Крим, латентність злочинності, ймовірно їх рівень ще вищий;

2) за досліджуваний період коефіцієнт інтенсивності стосовно всіх злочинів проти життя та здоров'я особи був найвищим у 2013 р. (на 100 тис. населення припадало 158 злочинів). Коефіцієнт злочинної активності населення був найвищий у 2019 р. (на 100 тис. населення - 53 злочини). Щодо умисних вбивств - найвищий індекс інтенсивності зафіксовано у 2014 р. (25 злочинів на 100 тис. населення), а найвищий індекс злочинної активності - у 2016 р. (3 умисні вбивства на 100 тис. населення);

3) питома вага злочинів проти життя та здоров'я особи у структурі злочинності становить 
9,5\%. Частка насильницьких злочинів у структурі злочинів проти життя та здоров'я особи складає $96 \%$;

4) відзначається стабільність основних структурних показників злочинів проти життя та здоров'я особи (84 \% складають злочини проти здоров'я, 14,3 \% - злочини проти життя, 1,96 \% злочини, що ставлять у небезпеку життя та здоров'я особи). Найбільш поширеними у структурі злочинів, передбачених розділом II Особливої частини КК України є: умисні легкі тілесні ушкодження (питома вага - 63,7 \%), умисні вбивства без обтяжуючих та пом'якшуючих обставин (питома вага - $12 \%$ ), умисні середньої тяжкості тілесні ушкодження (питома вага - 7,2 \%), умисні тяжкі тілесні ушкодження (питома вага - 4,9\%), побої і мордування (питома вага - 3,2 \%);

5) стрімке зростання рівня злочинів проти життя та здоров'я особи у 2013-2014 рр., а також збільшення питомої ваги їх насильницького сегменту майже до $100 \%$, свідчить не лише про їх сімейно-побутовий і ситуаційний характер, а й про вагому роль суспільно-політичної складової їх обумовлення.

\section{Джерела та література}

1. Кримінальне право України. Особлива частина: підручник / Ю. В. Александров, О. О. Дудоров, В. А. Клименко та ін.; за ред. М. І. Мельника, В. А. Клименка. - К.: Юрид. думка, 2004. - 656 с.

2. Статистична інформація. Про зареєстровані кримінальні правопорушення та результати їх досудового розслідування (2013-2019 рр.) [Електронний ресурс]. - Режим доступу: http://www.gp.gov.ua/ua/stst2011.html?dir_id=111482\&libid=100820\&c=edit\&_c=fo.

3. Єдиний звіт про осіб, які вчинили кримінальні правопорушення (2016-2019 рр. [Електронний pecypc]. - Режим доступу: http://www.gp.gov.ua/ua/stst2011.html?dir_id=111482\&libid=100820\&c=edit\&_c=fo. 4. Стан та структура злочинності в Україні. Департамент інформаційно-аналітичного забезпечення $\mathrm{MBC}$ України [Електронний ресурс]. - Режим доступу: http://mvs.gov.ua/mvs/control/ main/uk/publish/article/717134.

Старко А. Преступления против жизни и здоровья человека: количественнокачественные показатели в 2013-2019 гг. Статья посвящена проблеме криминологической характеристики преступлений против жизни и здоровья человека на современном этапе. В частности, исследуется вопрос о количественно-качественных показателях данного вида преступности за период 2013-2019 гг. Количественно-качественные измерения преступности служат одним из основных ориентиров как для коррекции введенных мер предупреждения, так и поиска новых и эффективных способов противодействия и должны быть постоянным объектом системного криминологического наблюдения. 2013-2014 гг. отличились эскалацией количественно-качественных измерений преступлений против жизни и здоровья человека, а показатели за 2015-2019 гг. характеризуются последующей стабилизацией и тенденцией к снижению. Преступления против жизни и здоровья человека, и особенно их насильственный сегмент, за последние семь лет достиг 96\%, характеризуются высокой степенью общественной опасности. Приводятся данные об уровне преступлений и лиц, их совершивших, коэффициентах, характеризующих криминальную активность населения и интенсивность преступлений этого вида на территории Украины. Осуществлен анализ структуры преступлений, а также структуры соответствующих групп преступлений. Автором констатировано стабильность основных структурных показателей преступлений против жизни и здоровья человека (84\% составляют преступления против здоровья, 14,3\% - преступления против жизни, $1,96 \%$ - преступления, ставящие в опасность жизнь и здоровье человека ). Наиболее распространенными являются: умышленные легкие телесные повреждения $(63,7 \%)$, умышленные убийства без отягчающих и смягчающих обстоятельств (12\%), умышленные средней тяжести телесные повреждения (7,2\%), умышленные тяжкие телесные повреждения $(4,9 \%)$, побои и истязания $(3,2 \%)$. Констатирован стремительный рост уровня преступлений против жизни и здоровья человека в 2013-2014 гг., а также увеличение удельного веса их насильственного сегмента почти до $100 \%$, что свидетельствует не только об их семейно-бытовом и ситуационном характере, но и о весомой роли общественно-политической составляющей их обусловленности.

Ключевые слова: преступления против жизни и здоровья человека, убийства, телесные повреждения, уровень, структура, уровень преступности, статистические данные. 
Starko O. Crimes Against Human Life and Health: Quantitative and Qualitative Indicators for 2013-2019. The article deals with the issue of the criminological characterization of crimes against life and health of a person. In the focus of the study are quantitative and qualitative indicators of this crime type in the period 2013-2019. Quantitative and qualitative measurements of crime serve as one of the main guidelines both for the correction of the introduced prevention measures and for the search for new and more effective ways of counteraction, and therefore should be a constant object of systematic criminological surveillance. 2013-2014 were marked by an escalation of quantitative and qualitative measurements of crimes against life and health, and 2015-2019 were marked by further stabilization of slightly reduced indicators. Crimes against the life and health, and especially their violent segment, which has reached $96 \%$ in the last seven years, are characterized by a high degree of public danger. The article provides the data on the level of crimes and persons who committed them, the coefficients that characterize the criminal activity of the population, and the intensity of crimes of this type in Ukraine. The author analyzes the structure of crimes, including the structure of the relevant groups of crimes. The study has revealed the stability of the key structural indicators of crimes against human life and health (84\% are crimes against health, $14.3 \%$ - crimes against life, $1.96 \%$ - crimes that endanger the life and health of a person. The most common among them are: premeditated minor bodily injuries $(63.7 \%)$, premeditated murders without aggravating and mitigating circumstances $(12 \%)$, premeditated moderate bodily injuries $(7.2 \%)$, intentional grievous bodily harm (4.9\%), beatings and tortures $(3.2 \%)$. The rapid growth of crimes against life and health of a person in 2013-2014 and the increase in the share of their violent segment to almost $100 \%$ indicate not only their home or situational nature but also manifest the importance of the social-political component in their emergence.

Key words: crimes against life and health of a person, murders, bodily injuries, level, structure, crime rates, statistical data.

УДК 343.288

DOI https://doi.org/10.32782/2409-4544/2020-1/22

Ю. Фідря

\section{Вчинення злочину на грунті статевої приналежності як обставина, яка обтяжус покарання}

У статті проаналізована одна 3 обставин, що обтяжують покарання, яка включена до Кримінального кодексу України як наслідок реалізації вимог Стамбульської конвенції, а саме вчинення злочину на грунті статевої приналежності. Зміст цієї обставини полягає в негативному i зневажливому ставленні винної особи до представників певної статі або неприйняття представників певної статі. Включення цієї обставини, що обтяжує покарання, до кола тих, які суд обов'язково повинен врахувати при призначенні покарання, підтвердить чіткі наміри держави не толерувати в демократичному суспільстві прояви ненависті та відкритої зневаги до особи у зв'язку із іiі приналежністю до певної статі. Водночас держава не повинна дозволяти протиправної поведінки на грунті сексуальної орієнтації чи гендерної приналежності. Відзначено некоректність формулювання даної обставини в світлі гендерного контексту Стамбульської конвенції, адже ії чинна редакція не охоплює сексуальної орієнтації та гендерної приналежності, а застосування закону про кримінальну відповідальність за аналогією заборонено. Недосконалість прийнятої термінології, підміна понять в Кримінальному кодексі України породжує проблему низької ефективності норми і недосконалості механізму іiі реалізації на практиці. Перш за все, значні труднощі можуть виникнути в ході іiі виявлення, а також доведення. Запропоновано внести зміни в п. 3 ч. 1 ст. 67 Кримінального кодексу України і сформулювати дану обставину, що обтяжує покарання, наступним чином: «вчинення злочину на грунті расової, національної або релігійної ворожнечі або ворожнечі, або на грунті сексуальної орієнтації, статевої або гендерної приналежності».

Ключові слова: обставини, які обтяжують покарання, статева приналежність, гендер, Стамбульська конвенція, гендерно обумовлене насильство.

(С) Фідря Ю., 2020 